\title{
Sağlık psikolojisi bakış açısından karar anı teşviklerinin merdiven kullanımı üzerindeki etkileri
}

\author{
Nermin Taşkale ${ }^{a}$,̈zlem Sertel Berk \\ a Arş. Gör., İstanbul Üniversitesi Edebiyat Fakültesi Psikoloji Bölümü, Laleli, İstanbul \\ b Doç. Dr., İstanbul Üniversitesi Edebiyat Fakültesi Psikoloji Bölümü, Laleli, İstanbul
}

Geliş tarihi: 14.08.2015, Kabul tarihi: 01.03.2016

\begin{abstract}
Özet
Amaç: Bu çalışma güçlü bir fiziksel aktivite olan merdiven kullanımını artırmada karar anı teşviklerini kullanan çalışmaları gözden geçirmektedir. Gereç ve Yöntem: Bu derleme, 19952015 yılları arasında yayımlanmış olan yürüyen merdiven yerine merdiven kullanmayı artırmayı inceleyen çalıșmaları içermektedir. Arama "EbscoHOST", "JSTOR", "Medline", "ProQuest", "PsychInfo", "Sage", "ScienceDirect", "TÜBİTAK ULAKBİM" ve "Wiley Online Library" veri tabanlarında "merdiven, yürüyen merdiven, asansör, fiziksel aktivite, tanıtım, uygulama" anahtar kelimeleri kullanılarak Türkçe ve İngilizce dilindeki yayınlarla gerçekleștirilmiștir. Bulgular: Karar anı teşvikleri ile merdiven kullanımını artırmayı amaçlayan deneysel çalışmaların gözden geçirilmesi, bu teşviklerin merdiven kullanımını artırmada başarılı bir müdahale olduğunu göstermektedir. Bu teşvikler bir davranışsal ipucu olarak işlev görmekte ve mesajlar yarar, engel ve duyarlılık algılarını etkileyerek ve öz-etkinlik inançlarını yükselterek bireyleri merdiven kullanmaya yönlendirmektedir. Sonuç: Karar anı teşvikleri kullanımı merdiven kullanımını artırmada başarılı bir yöntemdir. Davranışsal bir ipucu görevi yapar. Bununla beraber, mesajların alt grupların özgül ihtiyaçlarına hitap edebilmesi için, bu teşviklerin kuramsal arka planını değerlendirecek çalışmalara gereksinim vardır.
\end{abstract}

Anahtar Kelimeler: Merdiven kullanımı, karar anı teşviki, sağlık davranışı kuramları

Sorumlu Yazar: Nermin Taşkale, İstanbul Üniversitesi, İstanbul Üniversitesi Edebiyat Fakültesi Psikoloji Bölümü, Ordu Cad. No. 196, 34459 Laleli, İstanbul Tel: 02124555700 15815 E-mail: nermin.taskale@istanbul.edu.tr

Copyright holder Turkish Journal of Public Health

This work is licensed under a Creative Commons Attribution-NonCommercial 4.0 International License. $(\mathrm{cc}) \mathrm{EY}-\mathrm{Nc}$ 


\title{
The effects of point of decision prompts on stair use from the perspective of health psychology
}

\begin{abstract}
Objective: This study reviews studies which have used point of decision prompts to increase stair use, as a vigorous physical activity. Methods: This review included studies dealing with increasing stair use as opposed to escalator use that have been published between 1995-2015. The search was conducted in Turkish and English language publications using the keywords "stair, escalator, elevator, physical activity, promotion, implementation" in "EbscoHOST", "ISTOR", "Medline", "ProQuest", "Sage", "ScienceDirect", "TÜBITTAK ULAKBIM" and "Wiley Online Library" databases. Results: Review of experimental studies which aim to increase stair use by point of decision prompts showed that use of such prompts is a successful implementation in increasing stair use. These prompts function as a cue for action and messages direct people to use stairs, by affecting benefit, barrier and susceptibility attributions and enhancing self-efficacy beliefs. Conclusions: The use of point of decision prompts is a successful method to increase stair use. It serves as a cue for action. However, there is a need for future studies to evaluate the theoretical backgrounds of such prompts in order for messages to address special needs of subgroups.
\end{abstract}

Keywords: Stair use, point of decision prompts, health behavior theories

\section{Giriş}

Egzersiz en temel anlamda fiziksel aktivitenin bir boyutu olarak ele alınabilir. ${ }^{1}$ $\mathrm{Bu}$ yaklaşım fiziksel aktiviteyi, kaslarda üretilen ve enerji harcamaya sebep olan herhangi bir vücut hareketi, egzersizi ise vücut sağlığının bir ya da birden fazla parçasını geliştirme ya da korumaya yönelik planlı, yapılandırılmış, tekrarlı ve amaçlı fiziksel aktivite olarak tanımlamaktadır. Fiziksel aktivitenin ölüm oranı azaltmadaki etkinliğini ortaya koyan araştırmalar, fiziksel aktivitenin bir alt başlı̆g olan egzersiz davranışını geliştirme ve artırmanın da önemini ortaya koymaktadır. ${ }^{2}$ Bununla beraber planlı ve tekrarlı davranış gerçekleştirmenin zaman alması, davranışın gerçekleştirilmesi sırasında verilen olumlu geribildirimin azlığı ve tek başına gerçekleştirilen bu davranış için yardım alınamaması gibi sebepler düzenli egzersiz davranışının ortaya koyulmasını engellemektedir. ${ }^{3}$ Son dönemde gerçekleştirilen çalışmalar ise günlük yaşam egzersizlerinin düzenli egzersiz ile benzer faydalar sağladığını göstermektedir. ${ }^{4}$ Dahası, bu egzersizlerin tek seferlik ve uzun süreli ya da çok tekrarlı ve kısa süreli olması arasında fayda sağlama bakımından anlamlı bir fark bulunmamıștır. ${ }^{5}$ Kısa ve anlık egzersizlerin büyük planlamalar gerektirmemesi nedeniyle alışkanlık ve yerleşik normlar gibi davranışa yönelik engellerle karşılaşılmasını azaltacağı düşünülmektedir. ${ }^{6} \mathrm{Bu}$ bağlamda ele alındığında günlük hayatta gerçekleștirdiğimiz pek çok davranış bir egzersiz davranışı olarak tanımlanabilmektedir.

Günlük hayatta gerçekleștirdiğimiz egzersiz davranışlarına güçlü bir örnek asansör ya da yürüyen merdiven yerine 
merdiven kullanımıdır. Merdiven kullanımı anlık, kısa, tekrarlı bir egzersiz davranışı örneği teşkil etmektedir. On beş santimetrelik bir merdiven basamağını çıاkma ve inme sırasıyla 0.11 ve $0.05 \mathrm{kcal}$ enerji harcanmasina neden olur. ${ }^{7} \mathrm{Bu}$ özellikler sebebiyle, merdiven kullanımı (özellikle merdiven çıkma) yer çekimine karşı yapılan iş de göz önünde bulundurulduğunda yürüme gibi orta dereceli fiziksel aktivitelerden üstün ve güçlü bir fiziksel aktivitedir. ${ }^{8}$ Egzersizin kardiyovasküler hastalıklar, diyabet ve kanser gibi pek çok hastalık için koruyucu rolü ${ }^{9}$ düşünüldügünde merdiven kullanımının bir fiziksel aktivite olarak önemi ortaya çıkmaktadır. $\mathrm{Bu}$ durum merdiven kullanımının Amerika Birleşik Devletleri Sağlı ve İnsan Hizmetleri Bakanlığı'nın obeziteye karşı önerdiği 100 yaşam değişimi adımından biri olmasını sağlamıştır.10 Koruyucu sağlık davranışlarının maliyet etkinliğinin yüksek olduğu yönündeki çalışmalar düşünüldüğünde ${ }^{9}$ merdiven kullanımının planlı ve tekrarlı hale getirilmesinin bireylerin günlük egzersiz ihtiyacını karşılayabileceği ve önemli bir koruyucu sağlık davranışı olabileceği ortaya çıkmaktadır.

Günlük hayatta sık karşılaşılan ve egzersize katkısı büyük olan merdiven kullanımını artırmaya yönelik pek çok deneysel çalışma ve bunlara ilişkin gözden geçirme çalışması yapılmıştır.11,12 Değinilen gözden geçirme çalışmaları ele alındığında öne çıkan müdahale türünün karar anı teşviki müdahalesi olduğu görülmektedir. Karar anı teşvikinde amaç bireylerin basamaklı merdiven ya da asansör/yürüyen merdivenle karşılaştığı o anda basamaklı merdivene yönelmesini sağlamaktır. $\mathrm{Bu}$ yönlendirme işaretçiler, posterler, şeritler üzerinde görseller ya da metinler aracılığıyla yapılabilir. $\mathrm{Bu}$ konuda gerçekleştirilen çalışmalar karar anı teşvikinin merdiven kullanımını artırmada başarılı bir yöntem olduğunu ortaya koymuştur. ${ }^{10-13}$ Çalışmaların bir kısmını metaanaliz olarak ele alan başka bir çalışma ile de olumlu yöndeki bulgular istatistiksel anlamda desteklenmiştir. ${ }^{14} \mathrm{Bu}$ çalışmaları anlamlı kılan bir başka nokta da karar anı teşviki uygulamalarının alış veriş merkezi
(AVM), metro, tren istasyonları gibi ortamlarda gerçekleşmiş olmasıdır. Özellikle AVM'ler düşünüldüğünde, bireylerin hareketliliklerindeki baskın motivasyon olumlu sağlık sonuçları elde etmek değil ilgi çekici ve birbiriyle bağlantısı yüksek olan mağazalara yönelmektir ve bina planlamaları bu bilgiler ışığında yapılandırılmaktadır. ${ }^{15}$ Dolayısıyla, bu gibi ortamların sağlık kavram, uygulama ya da sonuçlarıyla doğrudan bağlantısı olmadiğı halde gerçekleştirilen müdahalelerin basamaklı merdiven kullanımı gibi spesifik bir sağlık davranışını artırma bakımından olumlu sonuçlar vermesi önemlidir.

Anılan çalışmalar bütün olarak ele alındığında son derece kapsamlı gözden geçirme çalışmalarına yer verildiği görülmektedir. Bununla beraber mevcut gözden geçirme çalışmalarının merdiven kullanımına karşı tercih seçeneği (asansör ya da yürüyen merdiven), çalışma ortamı, merdivenin basamak sayısı ve en önemlisi teşvik mesajının içeriğine yeterince eğilmemiş olması nedeniyle yeni bir gözden geçirme çalışmasına ihtiyaç duyulmaktadır. Şimdiki gözden geçirme çalışmamız bu açı̆̆ı gidermeyi hedeflemektedir.

\section{Gereç ve Yöntem}

Merdiven kullanımını artırmaya yönelik deneysel çalışmaları derlemek amacıyla bu araştırmada yeni bir kaynak taraması gerçekleștirilmiştir. Çalışma gözden geçirme çalışması olması sebebiyle herhangi bir deneysel yöntem ya da uygulama içermediğinden bir etik başvuru sürecine gereksinim duyulmamıştır. Çalışmalara erişimde "merdiven, yürüyen merdiven, asansör, fiziksel aktivite, tanıtım, uygulama" kelimeleri "EbscoHOST", "JSTOR", "Medline", "ProQuest", "PsychInfo", "Sage", "ScienceDirect", "TÜBITTAK ULAKBIM" ve "Wiley Online Library" veri tabanlarında Türkçe ve İngilizce dilinde sunularak 1995-2015 yılları arasındaki yayınlar için makale araması yapılmıştır. Karşılaşılan çalışmalarda manipülasyonun çok yüksek oranda karar anı teşviki ile sağlandığı görülmüştür. Bu sebeple arama terimlerinde bir değişikliğe gidilmese dahi 
erişilen çalışmalarda kullanılan müdahale türü karar anı teşviki olmuştur. Çalışmaların çoğunda merdivene karşılık sunulan seçenek yürüyen merdiven iken önemli bir kısmında da merdivene karşılık sunulan seçenek asansör olmuştur. Bununla beraber karar anı teşviklerinin uygulamasında asansörlerin merdivenlere uzak mesafede olması ya da merdivenlerin asansörlere nazaran daha zor ulaşılır olması gibi binanın yapısal uygun(suz)luğu önemli bir karıştırıcı değișken olmaktadır. Bu sebeple erişilen makalelerden yalnızca merdivene karşılık yürüyen merdivenin sunulduğu yayınlar incelemeye alınmıştır. Elde edilen çalışmaların referans listeleri taranarak araştırmaya merdiven kullanımını artırmada karar anı teşviki müdahalesini kullanan başka çalışmalarda eklenmiştir. Karşılaşılan makaleler tarandığında 25 adet deneysel çalışmaya erişilmiştir. $\mathrm{Bu}$ çalışmalar gerçekleştirildiği mekan, merdivenin basamak sayısı, kullanılan teşvik, mesaj içeriği ve biçimlendirici ya da kontrol değişkenleri de göz önünde bulundurularak EK-Tablo 1'de özetlenmiştir (EK-Tablo 1 makalenin sonunda sunulmuştur).

\section{Bulgular}

Pek çoğu batı kaynaklı olmakla beraber farklı kıta ve kültürlerden bulguları içeren çalışmalarda kullanılan araştırma tasarımının müdahale öncesi ve sonrası gözlem sayılarının karşılaştırıldığı zaman serisi analizi yöntemi olduğu görülmektedir. İnceleme kapsamındaki çalışmaların tümünde müdahale sürecindeki merdiven kullanımı temel düzey sürecindeki merdiven kullanımından yüksektir. $\mathrm{Bu}$ sonuç son dönemde gerçekleştirilen gözden geçirme çalışmaları bulgularıla tutarlıdır.11,13 Bununla beraber edinilen kazanımın izleme sürecinde kaybedildiği görülmüștür. Çalışma süresi beș gün ve izlemelerle birlikte iki yıla kadar yayılan bir süreyi kapsamakla birlikte müdahalenin uygulama süresi bir gün ile 10 hafta arasında değişmektedir. Seçilen müdahale süresinin uzunluğunun neye göre belirlendiği çalışmalarda belirtilmemiştir. Çalışmaların 11'i alışveriş merkezinde, yedisi tren istasyonunda, altısı metroda, biri işyerinde gerçekleşmiştir. Kullanılan birbirinden farklı mekanlarda en yoğun saatler gözlem için hedeflenerek örneklemin evreni en iyi şekilde yansitması hedeflenmiştir. Buna rağmen gözlem yapılan saatler ve mekanlardaki insan yoğunluğunun çalışma sonuçlarına yansımaması için bu değişken pek çok çalışmada kontrol değişkeni olarak ele alınmıştır. Bununla beraber çalışmaların hiçbirinde değinilmemiş olan önemli bir nokta günümüzde özellikle insan kalabalığının yoğun olduğu yerleşim birimlerinde yürüyen merdivene yönelen pek çok bireyin onu bir hareketsizlik nesnesi olarak değil zaman ve enerji tasarruflu bir yürüyüş alanı olarak kullanmasıdır. Derlenen çalışmalarda yürüyen merdivenlerde yürümenin gözlemlerden dıșlanıp dıșlanmadığı ya da nasıl ele alındığına ilișkin bir bilgi yoktur. Yürüyen merdivenlerde yürüyen bireylerin harcadığı enerjinin adımlanan basamak sayısındaki azalma sebebiyle merdiven kullananlara göre daha az olması beklenmekle beraber yürüyen merdivenlerin ergonomik açıdan adımlamaya uygunsuz oluşunun harcanılan enerji miktarı ya da sağlık bakımından ne gibi etkileri olduğu belirsizdir.7,16 Bu gözden geçirme çalışmasının kapsadığı makalelerin genelinde merdivenlerin basamak sayısı 1540, binaların kat sayısı 2-6 arasında değişmektedir.

Büyük oranda olumlu sonuçlar sergileyen çalıșma sonuçları bazı kontrol ya da biçimlendirici değişkenler bakımından incelenmiștir. Araștırmalar birlikte ele alındığında ortaya çıkan önemli bir faktör pek çok çalışma boyunca insan yoğunluğunun kontrol edildiğidir. Bu durum önceki çalıșmaların insan yoğunluğunun gözlem sayısını etkileyebileceği yönündeki bulgularıyla benzerdir.17 Daha önceki çalıșmaların bulgularıyla da paralel olarak kadınlara oranla erkeklerin, kilolu olanlara oranla kilolu olmayanların, yaşlılara oranla gençlerin ve çanta taşıyanlara oranla taşımayanların merdivenleri daha sık kullandığı görülmüştür. ${ }^{18} \mathrm{Bu}$ durum kadınların ve yaşlıların kas tonunun daha zayıf olması, kilolu olmanın ve çanta taşımanın merdiven kullanırken harcanacak enerji oranını artırmasıyla açıklanabilir. Bu 
gibi örneklerde daha çok enerji harcayacak olmanın bireylerin engel algılarını güçlendirmekte olduğu düşünülebilir. ${ }^{19}$ Sağlık İnanç Modeli kapsamında ele alınan engel algısının davranışın en güçlü belirleyicisi olduğu düşünüldüğünde bu sonuç şaşırtıcı değildir.20,21

Çalıșmalarda kullanılan teșvikler poster, şerit, ayak izi şeklindedir. Bunlardan ayak izi yalnızca yönlendirme yaparken şerit ve posterler görsel ya da yazılı mesajlar içermektedir. $\mathrm{Bu}$ sebeple ayak izlerinin algısal müdahale etkinliğinin daha az boyutlu olduğu düşünülebilir. Poster ve şeritler karşılaştırıldığında ise şeritler yalnızca merdiven basamak içlerine yapıştırılırken posterler merdiven başlangıç ve sonunda yere, duvarlara ya da tavana asılabilmektedir. Ayrıca, insan yoğunluğunun çok artabildiği istasyon gibi mekanlarda merdivenlerdeki şeritlerin görünürlüğü imkansız hale gelebilmekte ve bu durum müdahalenin etkililiğini daha başından düşürebilmektedir. ${ }^{22} \mathrm{Bu}$ durum posterlerin görülme ihtimalinin daha yüksek olduğu şeklinde yorumlanabilir. Bununla beraber daha önceki çalıșmalar incelendiğinde $297 \mathrm{~cm} * 420 \mathrm{~cm}$ boyutlarından büyük posterlerin görünür olduğu, bu boyuttaki ya da daha küçük posterlerin ise fark edilemeyebilecekleri görülmüştür. ${ }^{17}$

Karar anı teșvikinin görünürlüğü ve etkilerine ilişkin bu sonuçlar gerçekleştirilen uygulamaların örgütsel ortama etkili bir müdahale olduğunu bir kez daha hatırlatmaktadır.23 Gerçekleştirilen müdahale ne kadar etkili olursa olsun hem deneysel hem de kuramsal çalışmaların ortaya koyduğu gibi mimari ya da yapısal faktörler dikkate alınmalıdır.16,22 Ayrıca, müdahale gerçekleștirilmeden önce kişilerin buna hazır olup olmadığına ilişkin incelemelerin yapılması ve gerekirse teşviklerin kişisel ihtiyaçlara göre şekillendirilmesi gerekmektedir. ${ }^{24-27}$

Tabloda ele alınan bir diğer başlık olan mesaj içeriği bir anlamda müdahalenin temelini oluşturmakla beraber buna ilişkin herhangi bir niteliksel çalışmaya rastlanmamıştır. $\mathrm{Bu}$ sebeple çalışmalarda kullanılan mesajların içeriğine ilişkin bir özetlemeye ihtiyaç vardır. Kullanılan mesajlar incelendiğinde özellikle merdiven kullanılmasını ögütlemede "Merdiven çlkmak bir dakika hafif tempolu koşudan daha fazla kalori yakar." gibi geniş zaman ve "Merdivenleri kullan, sağlıklı kal." gibi emir kipi içeren cümlelerin sıkça tercih edildiği görülmüştür. $\mathrm{Bu}$ tercihle karar anı teşvikinin "şimdi" ve "burada"yı vurgulamasının sağlandığı ve geçmiş deneyimler ve alışkanlıkların etkisinin azaltıldığı düşünülebilir. ${ }^{28}$ Mesaj içerikleri ele alındığında 14 çalışmada sağlık, yedi çalışmada kilo kaybı/kontrolü, altı çalışmada zaman, beş çalışmada tebrik/olumlu geribildirim ve bir çalışmada aile temasına değinildiği görülmektedir (Tablo 1). $\mathrm{Bu}$ durum sağlık temalı motivasyonların mesajlarda sıkça yer aldığı yönündeki daha önceki bulgularla örtüșmektedir.10 Temalara ilișkin bu sinıflandırma temelinde merdiven çıkmayı bir egzersiz türü ve sağlık davranışı olarak ele alan çalışmaların hedeflerine ilişkin açık mesajlar sunduğu düşünülebilir. Ayrıca kilo kontrolünün ikinci sı tema olması egzersizin yanında kilo kontrolünün de hedeflenerek iki sağlık davranışına yönelik mesajın bir arada verildiği şeklinde yorumlanabilir. Benzer șekilde fazla kilolu bireyler için kilo kaybı/kontrolü temalı müdahalelere verilen tepkinin yalnızca sağlık koruma temalı müdahalelere verilen tepkiden daha yüksek olduğu belirtilmiştir. ${ }^{29}$ Bununla birlikte, incelenen diğer çalışmalar farklı mesaj içerikleri bakımından sağlık sonucunun nasıl şekillendiğine ilişkin bilgi vermemektedir.

$\begin{array}{ccr}\text { Çalışmalarda kullanılan } & \text { mesajların } \\ \text { hedefledikleri } & \text { temalara } & \text { ilișkin }\end{array}$ gerçekleștirilen özetleme, bilgiyi derleme bakımından faydalı olmakla beraber geçerlilik ve güvenirlikten yoksun öznel bir sinıflama ve ifade biçimidir. Mesaj içeriklerinin nesnel değerlendirilmesi için kuramsal temelde bir sunuma ihtiyaç vardır. Merdiven kullanma davranışını karar anı teşviki yoluyla artırmayı ele alan çalışmalarda herhangi bir kurama atıfta bulunulmamıştır. $\mathrm{Bu}$ sebeple yazının devamında çalışmalarda kullanılan mesaj içerikleri Glanz, Rimer ve Viswanath ${ }^{30}$ tarafından kapsamlı bir biçimde sunulan sağlık kuramları bakımından ele alınacaktır. 
Herhangi bir karar anı teşvikinin kullanımı, ortama yapılan çoklukla görsel bir müdahaledir. Teşviklerin sunulmasıyla mesajı gören bireylerin alışkanlıklarına ters davranışları sergilemeye karar vermesi hedeflenmektedir. Her iki durumda da mesaja uyumlu ya da uyumsuz karar verme anlık bir süreçtir. Mesajların bu süreçteki rolü, var olan bilişsel ya da duygusal yapılanmaya müdahale etmek değil yalnızca istenen davranışa geçmek için bir teşvik sunmaktır. $\mathrm{Bu}$ bakımdan ele alındığında (yalnızca bir işaret veya metin içeren poster ya da şerit olsun) karar anı teşviklerinin Sağlık İnanç Modeli'ndeki18 davranışsal ipuçlarına örnek teşkil edebileceği düşünülebilir. Böylesi bir ipucu ile davranışın en büyük belirleyicisi olan davranış motivasyonunun artırılması hedeflenmektedir. ${ }^{31,32}$ Burada amaç kişileri merdiven kullanma eylemi öncesi bir evreden merdiven kullanma eylemi evresine geçirmektir. ${ }^{25,26}$ Karar anı teşvikinin bu evre geçişinde hızlandırıcı rolü olduğu düşünülebilir. ${ }^{33}$ Karar anı teşvikleri yoluyla bir anlamda bireylere öz-etkinlik inançlarl ${ }^{34}$ hatırlatılmakta ve davranışı gerçekleștirebileceğine ilişkin "merdivenleri kullanın" ögüdü sunulmaktadır. Öz-etkinlik her ne kadar Bandura'nın ${ }^{34}$ ortaya attığı bir sosyal öğrenme kavramı olsa da Sağlık İnanç Modeli19, Planlanmış Davranış Kuramı ${ }^{31}$, Bütünleştirilmiş Davranıș Modeli ${ }^{32}$ ve Transaksiyonel Stres Modeli ${ }^{35}$ gibi pek çok sağlık kuramında da yer verilen bir kavramdır. Karar anı teşviki olarak davranışsal ipucu kullanımının bir başka amacının da Bütünleştirilmiş Davranıș Modeli'nde $^{32}$ de değinilen ve davranıșı şekillendirmede doğrudan etkili bir değişken olan alışkanlıklara karşı bir ipucu oluşturmak olduğu düşünülebilir. Bununla beraber, davranışsal ipuçları Sağlık İnanç Modeli içerisinde modele sonradan eklenen ve en az çalışılan kavramdır. ${ }^{19,20}$ Bu sebeple yazının devamında anılan çalışmalarda kullanılan karar anı teşviklerinin içeriğine odaklanılarak nasıl bir bağlamda ipucu teşkil ettiklerine değinilecektir.

Karar anı teşviki mesajların metinsel içeriklerine odaklanıldığında, bu içerikler orijinal çalıșmalarda herhangi bir kurama dayanılarak yazılmamış olsa da en çok değinilen yapının Sağlık İnanç Modeli'ndeki yarar inancı olduğu düşünülebilir.19 "Sağlıklı kalın, zaman kazanın, merdivenleri kullanın" ya da "bel çevrenizi inceltin" gibi mesajlarla hedeflenen temelde merdiven kullanımı ile sağlanacak yararların gösterilmesi olduğu düşünülebilir. "Kalbinin egzersize ihtiyacı var" ya da "günde yedi dakika merdiven çlkmak kalbini korur" gibi mesajların ise yarar algısıyla beraber olası kardiyovasküler hastalıkları hatırlatarak yine aynı kuramda yer alan duyarlık

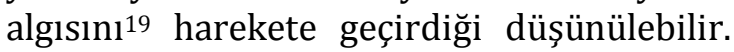
Duyarlık algısının koruyucu sağlık davranışını artırmadaki belirleyiciliğinin yüksek olduğuna ilişkin önceki çalışma bulguları düşünüldüğünde, duyarlık algısını da hedefleyen mesajların merdiven kullanmayı daha çok artırma ihtimali olabileceği ön görülebilir. ${ }^{21}$ Duyarlık kavramı Transaksiyonel Stres Modeli'nde de birincil değerlendirmenin bir alt başlığı olarak ele alınmaktadır. ${ }^{36}$ Gerek yarar gerek duyarlık algısını hedefleyen bu mesajlara "bedava egzersiz" ve "işte şansın" gibi mesajların eklenmesiyle mesajlara Bütünleştirilmiş Davranış Modeli'nde ${ }^{32}$ değinilen davranışın erişilebilirliğine ilişkin bir bilgi eklenmiş olduğu öne sürülebilir. Bu bilginin Sosyal Bilişsel Kuramın bir parçası olan davranışı hızlandırma etkisi ${ }^{33}$ sağladığı da düşünülebilir. Ayrıca, mesajların içinde şansa ve firsata atıfta bulunmanın Sağlık İnanç Modeli'nde ${ }^{19}$ değinilen ve sağlık davranışının ortaya çıkmamasını en güçlü şekilde belirleyen engel algısıni ${ }^{21}$ güçsüzleștirmeye hizmet ettiği söylenebilir. Engel algısı Planlanmış Davranış Kuramı ${ }^{31}$ ve Bütünleştirilmiş Davranış Modeli'nde ${ }^{32}$ kontrol inancı olarak isimlendirilmiş ve korunmuş güçlü bir yapıdır.

Sağlık davranışı üzerinde etkili olan algı ve tutumların yalnızca kişi içi düzeyde engel, yarar ve duyarlılık gibi kavramlarla değil kişilerarası düzeyde normlar temelinde de etkili olacağ Sağlık İnanç Modeli sonrasında geliştirilen kuramlarda bu kavramlara da yer verilmiştir. ${ }^{32}$ Değinilen araștırmalarda kullanılan karar anı teşviklerinde "aferin" gibi onaylayıcı geribildirimlerin başkalarının inanç ve beklentileri hakkında bilgi verdiği düşünülebilir. Bu geribildirimin Planlanmış Davranış Kuramı'nda ${ }^{31}$ başkalarının inançları yoluyla öznel norm, 
Bütünleştirilmiş Davranış Modeli'nde ${ }^{32}$ ise önleyici norm kavramlarıyla örtüştügü söylenebilir. $\mathrm{Bu}$ durum kişilerarası kuramlarda değinilen sosyal ağların sosyal destek ve sosyal etki sunma işlevleri ile paraleldir. ${ }^{37}$ Müdahalelerde sunulan "ailen için yap." şeklindeki mesajların ise farklı bir düzlemde Planlanmış Davranış Kuramı'nda $^{31}$ değinilen başkalarının beklentilerini hatırlatmayı hedeflediği düşünülebilir. $\mathrm{Bu}$ gibi mesajlarda aile gibi önemli bașkaları hatırlatılarak mesaj etkililiğinin artırılmaya çalışıldı ğı söylenebilir. Belirtilen mesaj içerikleri gerek kişi içi gerekse kişilerarası düzeyde birlikte ele alındığında ise şu anda görece daha rahat bir ulaşımla karşılaştırıldığında hareket edip enerji harcamayı gerektiren merdiven kullanımı geleceğe yönelik bir yatırım olarak sunulmakta ve bir anlamda doyum ertelemeye ve öz-düzenlemeye teșvik etmektedir. 38

Karar anı teşviklerinin içerik olarak farklı ve güçlü pek çok kurama yakın durduğu bu çalışmalar gözden geçirildiğinde herhangi bir mesaj içeriği sunmayan ayak izi ya da ok işaretlemeleri ile yapılan yönlendirmelere göre daha etkili sonuçlar vermesi beklenirken literatürde böyle bir karşılaștırmaya rastlanmamıştır. Bununla beraber, özellikle Türkiye'de gerçekleştirilen bir müdahalede ayak izi ya da ok işareti ile yönlendirme uygulamalarına benzer ve bu işaretleme sistemlerinin yönlendiriciliği de olmadan yürüyen merdivenlerin erişime kapatıldığ ya da durdurulduğu bir yönteme rastlanmıștır. ${ }^{39}$ Bir başka deyișle, karar anı teşviklerinde koruyucu bir sağlık davranışı olan merdiven kullanımı önerilirken yürüyen merdiven ya $\mathrm{da}$ asansörlerin durdurulması ile riskli davranışı önleme hedeflenmektedir. Bahsedilen müdahale idari organlarca gerçekleştirilen bir uygulama olup bilimsel bir çalışma değildir. Türkiye'de bu konuda gerçekleştirilen herhangi bir bilimsel çalışmaya ise Türkçe ya da İngilizce dilinde yapılan taramalarda rastlanmamıştır. Kaldı ki, bahsedilen örnekteki hedef riskli davranışı azaltmaya koruyucu davranışı artırmadan daha yakındır.

Günlük bir gazetede rastlanan müdahale 2012 yılı Dünya Yürüyüş Günü kapsamında yürüyen merdivenlerin 15 dakika durdurulmasına ilişkindir. ${ }^{39}$ Uygulamanın hedef davranış tanımında bir kapsam geçerliliği sorunu sebebiyle yürüme ve merdiven çıkma davranışını eş değer tuttuğu görülmektedir. Buna rağmen, uygulamanın hazırlıksız olması ve rasyonelinin açılklanmamış olması sebebiyle davranış değişimini ve bunun sürekliliğini belirleyebilecek atıf, tutum ya da normlara bir müdahalede bulunulmadığı görülmektedir. ${ }^{20}$ Tüm bunlara rağmen, o an ve o günlük bir davranışsal ipucu sağlayabilecek olan yöntem programın çalışılmamış olması sebebiyle kimi kişilerin asansörlere yönelmesini engelleyememiştir. Bu durum, AVM'lerin ortamsal olanaklarının merdiven kullanımını teşvik etmeye uygun olmayışıyla da açıklanabilir. ${ }^{16}$ Zira, genel kabul gören ergonomik düzeydeki merdiven basamağı yüksekliği ve genişliği ile yine genel kabul gören ergonomik düzeydeki yürüyen merdiven basamağı yüksekliği ve genişliği birbirinden farklıdır.40 Dolayısıyla, eğer uygulamadaki hedef davranış yürüyüş yapma değil de merdiven kullanımı olsaydı dahi böylesi bir uygulamanın başarı oranı yüksek olmayabilirdi.

\section{Tartışma}

Merdiven kullanımının günlük hayatta sık ve tekrarlı bir egzersiz davranışı olarak değerlendirilebilmesi merdiven kullanımını artırmanın önemini ortaya çlkarmıştır. ${ }^{8} \mathrm{Bu}$ durum merdiven kullanımını tercih anına yönelik karar anı teşviklerinin bir müdahale olarak uygulanmasına ve çalışılmasına dayanak oluşturmuştur.13,28 Konuya ilişkin metin süresince sunulan çalıșma sonuçları ve teşvikler birlikte incelendiğinde alışveriş merkezi ya da yolcu istasyonları gibi farklı mekanlarda, işaret, poster ya da şerit kullanılarak gerçekleștirilen karar anı teşvik müdahalelerinin genel anlamda olumlu sonuçlar verdiği görülmektedir. Karar anı teşviklerinde sunulan mesajların tema ve içerik bakımından daha ziyade bireysel sağlık kuramlarından Sağlık İnanç Modeli19, Planlanmış Davranış Kuramı ${ }^{31}$ ve Bütünleştirilmiş Davranıș Modeli'ne ${ }^{32}$ atıfta bulunduğu görülmektedir. Bunun dışında, mesajların ve teşviklerin öz-etkinliği 
kuramlar üstü bir yapı olarak ${ }^{30}$ hedeflediği düşünülebilir. $\mathrm{Bu}$ yollarla karar anı teşvikleri aracilığıyla davranışa alışkanlıklardan farklı yeni bir çerçeve tanıtılmakta ve bireylerin öz-düzenleme yapmaları beklenmektedir. ${ }^{38}$ Dolayısıyla, temel olarak davranışa yönelik o anda bir yönlendirme (Sağlık İnanç Modeli'nde davranışsal ipucu ${ }^{19}$ ) sunmayı hedefleyen karar anı teşviklerinin içerdikleri metinlerle davranış değişimini sağlayabilecek pek çok atıf, tutum ya da inancı kaçınılmaz olarak hedefledikleri görülmektedir.

$\begin{array}{lcrr}\text { Sağlık } & \text { kuramlarının } & \text { karar anı } \\ \text { teşviklerinde } & \text { kullanılan } & \text { mesajların } \\ \text { şekillendirilmesinde önemli } & \text { bir rol } \\ \text { oynayabileceği görülmekle beraber } & \text { ilgili } \\ \text { literatürde metin içeriği } & \text { bakımından } \\ \text { kuramsal } & \text { bir } & \text { incelemeye }\end{array}$
rastlanmamaktadır. Gelecek çalışmaların etkinliği büyük oranda ortaya koyulmuş olan karar anı teşviklerinin ${ }^{11}$ kuramsal açıdan nasıl şekillendirilebileceği ve bunun teşvik mesajlarını kişiye özgü biçimlendirmenin yolları üzerine eğilmesinde fayda olacaktır. Bu bağlamda, her ne kadar bu gözden geçirme çalışmasıyla karar anı teşviklerinde kullanılan mesaj içerikleri sağlık kuramları çerçevesinde incelenmiş olsa da bu incelemenin uygun nitel araştırma yöntemleriyle ortaya koyulmasına büyük bir ihtiyaç vardır. ${ }^{41}$ Ayrıca, karar anı teșviklerinin merdiven kullanımı üzerindeki etkisi incelenirken bu müdahalenin farklı eğitim, ekonomi düzeyleri ve sosyokültürel özelliklerle etkileșimi ${ }^{28}$ birlikte düşünülmeli ve program tasarlama, uygulama ve inceleme süreçleri bu bilgilerle zenginleștirilmelidir.

\section{Kaynaklar}

1. Caspersen CJ, Powell KE, Christenson GM. Physical Activity, Exercise, and Physical Fitness: Definitions and Distinctions for Health-Related Research. Public Health Res 1985;100(2):126-131.

2. Nocon $M$, Hiemann $T$, MüllerRiemenschneider F, Thalau F, Roll S, Willich SN. Association of Physical Activity with AllCause and Cardiovascular Mortality: A Systematic Review and Meta-Analysis. Eur J
Cardiovasc Prev Rehabil 2008;15(3):239246.

3. Sluijs EM, Kok GJ, van der Zee J. Correlates of Exercise Compliance in Physical Therapy. Phys Ther 1993;73(1):771-782.

4. Dunn AL, Marcus BH, Kampert JB, Garcia ME, Kohl HW, Blair SN. Comparison of Lifestyle and Structured Interventions to Increase Physical Activity and Cardiorespiratory Fitness: A Randomized Trial. JAMA 1999;281(4):327-334.

5. Macfarlane DJ, Taylor LH, Cuddihy TF. Very Short Intermittent vs Continuous Bouts of Activity in Sedentary Adults. Prev Med 2006;43:332-336.

6. Laitakari J, Vuori I, Oja P. Is Long-Term Maintenance of Health-Related Physical Activity Possible? An Analysis of Concepts and Evidence. Health Educ Res 1996;11(4):463-477.

7. Teh KC, Aziz AR. Heart Rate, Oxygen Uptake, and Energy Cost of Ascending and Descending the Stairs. Med Sci Sports and Exerc 2002;34:695-699.

8. LewisAL, Eves FF. Testing the Theory Underlying the Success of Point-of-Choice Prompts:A Multi-Component Stair Climbing Intervention. Psychol Sport Exerc 2012;12:126-132.

9. Roux L, Pratt M, Tengs TO, et al. Cost Effectiveness of Community-Based Physical Activity Interventions. Am J Prev Med 2008;35(6):578-588.

10. Dolan MS, Weiss LA, Lewis RA, Pietrobelli A, Heo M, Faith MS. 'Take the Stairs Instead of the Escalator': Effect of Environmental Prompts on Community Stair Use and Implications for a National 'Small Steps' Campaign. Obes Rev 2006;7:25-32.

11. Bellicha A, Kieusseian A, Fontvieille AM, Tataranni A, Charreire H, Oppert JM. Stair Use Interventions in Worksites and Public Settings: A Systematic Review of Effectiveness and External Validity. Prev Med 2015;70:3-13.

12. Dunn AL, Andersen RE, Jakicic JM. Lifestyle Physical Activity Interventions: History, Short- and Long-Term Effects, and 
Recommendations. Am J Prev Med 1998;15(4):398-412.

13. Nocon $M$, Müller-Riemenschneider $F$, Nitzschke K, Willich SN. Increasing Physical Activity with Point-of-Choice Prompts: A Systematic Review. Scand J Public Health 2010;38:633-638.

14. Webb OJ, Eves FF, Kerr JA. Statistical Summary of Mall-Based Stair-Climbing Interventions. J Phys Act Health 2011;8:558565.

15. Zacharis J, Bernhardt T, de Montigny L. Computer-Simulated Pedestrian Behavior in Shopping Environment. J Urban Plann Dev 2005;131:195-200.

16. Nicoll G. Spatial Measures Associated with Stair Use. Am J Health Promot 2007;21(4):347-350.

17. Kerr J, Eves FF, Carroll D. The Influence of Poster Prompts on Stair Use: The Effects of Setting, Poster Size and Content. Brit J Health Psych 2001;6:397-405.

18. Eves FF. Is There Any Proffitt in Stair Climbing? A Headcount of Studies Testing for Demographic Differences in Choice of Stairs. Psychon Bull Rev 2014;21:71-77.

19. Rosenstock IM. Historical Origins of the Health Belief Model. Health Educ Monogr 1974;2(4):328-335.

20. Champion VL, Skinner CS. The Health Belief Model. Glanz K, RimerBK, Viswanath $\mathrm{K}$, editörler. Health Behavior and Health Education: Theory, Research and Practice içinde. 4. Baskı. San Francisco: Jossey-Bass, 2008. s. 45-65.

21. Janz NK, Becker MH The Health Belief Model: a decade later. Health Educ Q 1984;11(1):1-47.

22. Olander EK, EvesFF, Puig-Ribera A. Promoting Stair Climbing: Stair-Riser Banners are Better than Posters... Sometimes. Prev Med 2008;46:308-310.

23. Butterfoss FD, Kegler MC, Francisco VT. Mobilizing Organizations for Health Promotion: Theories of Organizational Change. Glanz K, Rimer BK, Viswanath K, editörler. Health Behavior and Health Education: Theory, Research and Practice içinde. 4. Baskı. San Francisco: Jossey-Bass, 2008. s. 335-361.
24. Adams J, White MA. Systematic Approach to the Development and Evaluation of an Intervention Promoting Stair Use. Health Educ J 2002;61(3):272286.

25. Prochaska JO, DiClemente CC, Norcross JC. In Search of How People Change: Applications to Addictive Behaviors. Am Psychol 1992;47(9):1102-1114.

26. Weinstein ND, Lyon JE, Sandman PM, Cuite CL. Experimental Evidence for Stages of Health Behavior Change: The Precaution Adoption Process Model Applied to Home Radon Testing. Health Psychol 1998;17(5):445-453.

27. Kreuter MW, Strecher VJ, Glassman B. One Size does not Fit All: The Case for Tailoring Print Materials. Ann Behav Med 1999;21(4):276-283.

28. Booth SL, Sallis JF, Ritenbaugh C, ve ark. Environmental and Societal Factors Affect Food Choice and Physical Activity: Rationale, Influences and Leverage Points. Nutr Rev 2001;59(3):S21-S39.

29. Andersen RE, Franckowiak SC, Snyder J, Bartlett SJ, Fontaine KR. Can Inexpensive Signs Encourage the Use of Stairs? Results from a Community Intervention. Ann Intern Med 1998;129:363-369.

30. Glanz K, Rimer BK, Viswanath K. Health Behavior and Health Education: Theory, Research and Practice. 4. Baskl. San Francisco: Jossey-Bass, 2008.

31. Ajzen I. Perceived Behavioral Control, Self-Efficacy, Locus of Control, and the Theory of Planned Behavior. J Appl Psychol 2002;32(4):665-683.

32. Montaño DE, Kasprzyk D. Theory of Reasoned Action, Theory of Planned Behavior and the integrated behavior model. Glanz K, Rimer BK, Viswanath K, editörler. Health Behavior and Health Education: Theory, Research and Practice içinde. 4. Baskı. San Francisco: Jossey-Bass, 2008. s. 67-96.

33. Bandura A. Health Promotion from the Perspective of Social Cognitive Theory. Psychol Health 1998;13(4):623-649.

34. Bandura A. Self-Efficacy:The Exercise of Control. New York: Freeman, 1997 (Akt.: 
Bandura A. Health Promotion from the Perspective of Social Cognitive Theory. Psychol Health 1998;13(4):623-649.).

35. Lazarus RS. Coping Theory and Research: Past, Present and Future. Psychosom Med 1993;55:234-247.

36. Glanz K, Schwartz MD. Stress, Coping and Health Behavior. Glanz K, Rimer BK, Viswanath $\mathrm{K}$, editörler. Health Behavior and Health Education: Theory, Research and Practice içinde. 4. Baskl. San Francisco: Jossey-Bass, 2008. s. 211-236.

37. Heaney CA, Israel BA. Social Networks and Social Support. Glanz K, Rimer BK, Viswanath $\mathrm{K}$, editörler. Health Behavior and Health Education: Theory, Research and Practice içinde. 4. Baskı. San Francisco: Jossey-Bass, 2008. s. 189-210.

38. McAlister AL, Perry CL, Parcel GS. How Individuals, Environments and Health Behaviors Interact: Social Cognitive Theory. Glanz K, Rimer BK, Viswanath K, editörler. Health Behavior and Health Education: Theory, Research and Practice içinde. 4. Baskl. San Francisco: Jossey-Bass, 2008. s. 169-188.

39. Karaman BC. AVM'lerde Yürüyen Merdivenler Sağllk için 15 Dakika Durdu. Milliyet. 2012 Ekim 4. Erişim adresi: http://www.milliyet.com.tr/avm-lerdeyuruyen-merdivenler-saglik-icin-15-dakikadurdu/ekonomi/ekonomidetay/04.10.2012 /1606417/default.htm. Erișim tarihi: Ocak 5, 2015.

40. Eves FF, Lewis AL, Griffin C. Modelling Effects of Stair Width on Rates of Stair Climbing in a Train Station. Prev Med 2008;47:270-272.

41. Biggerstaff D. Qualitative Research Methods in Psychology. Rossi G, editör.Psychology: Selected Papers içinde, 2012. S. 175-206.Erişim adresi: http://www.intechopen.com/books/psycho logy-selected-papers/qualitative-researchmethods-in-psychology. Erişim tarihi: Ocak 10, 2015.

42. Blamey A, Mutrie N, Aitchison T. Health Promotion by Encouraged Use of Stairs. BMJ 1995;311:289-290.

43. Kerr J, Eves FF, Carroll D. Posters can Prompt Less Active People to Use the Stairs.
J Epidemiol Community Health 2000;54:942-943.

44. Coleman KJ, Gonzales EC. Promoting Stair Use in a US-Mexico Border Community. Am J Public Health 2001;91(12):2007-2009.

45. Kerr J, Eves FF, Carroll D. Six-Month Observational Study of Prompted Stair Climbing. Prev Med 2001;33:422-427.

46. Kerr J, Eves FF, Carroll D. Getting More People on the Stairs: The Impact of a New Message Format. J Health Psychol 2001;6(5):495-500.

47. Kerr J, Eves FF, Carroll D. Encouraging Stair Use: Stair-Riser Banners are Better than Posters. Am J Public Health 2001;91(8):1192-1193.

48. Webb OJ, Eves FF. Promoting Stair Use: Single versus Multiple Stair-Riser Messages. Am J Public Health 2005;95(9):1543-1544.

49. Andersen RE, Franckowiak SC, Zuzak KB, Cummings ES, Bartlett SJ, Crespo CJ. Effects of a culturally sensitive sign on the use of stairs in African American commuters. Soz Praventivmed 2006;51(6):373-380.

50. Iversen $M R$, Händel $M N$, Jensen $E N$, Frederiksen P, Heitmann BL. Effect of Health-Promoting Posters Placed on the Platforms of Two Train Stations in Copenhagen, Denmark, on the Choice between Taking the Stairs or the Escalators: A Secondary Publication. Int J Obes 2007;31:950-955.

51. Puig-Ribera A, Eves FF. Promoting Stair Climbing in Barcelona: Similarities and Differences with Interventions in EnglishSpeaking Populations. Eur J Pub Health 2009;20(1):100-102.

52. Nomura T, Yoshimoto Y, Akezaki Y, Sato A. Changing Behavioral Patterns to Promote Physical Activity with Motivational Signs. Environ Health Prev Med 2009;14:20-25.

53. Müller-Riemenschneider $F$, Nocon $M$, Reinhold T, Willich SN. Promotion of Physical Activity Using Point-of-Decision Prompts in Berlin Underground Stations. Int J Environ Res Public Health 2010;7(8):3063-3070.

54. Webb OJ, Cheng TF. An Informational Stair Climbing Intervention with Greater 
Effects in Overweight Pedestrians. Health Educ Res 2010;25(6):936-944.

55. Boen F, Maurissen K, Opdenacker J. A Simple Health Sign Increases Stair Use in a Shopping Mall and Two Train Stations in Flanders, Belgium. Health Promot Int 2010;25(2):183-191.

56. Ryan J, Lyon K, Webb OJ, Eves FF, Ryan CG. Promoting Physical Activity in a Low Socioeconomic Area: Results from an Intervention Targeting Stair Climbing. Prev Med 2011;52:352-354.

57. Sloan RA, Haaland BA, Leung C, MüllerRiemenschneider $F$. The Use of Point-ofDecision Prompts to Increase Stair Usage in Singapore. Int J Environ Res Public Health 2013;10:210-218. 
EK-Tablo 1. Merdiven kullanımına ilişkin erişilen çalışmaların özetlenmesi

\begin{tabular}{|c|c|c|c|c|c|c|c|}
\hline Çalışma & Mekan & $\begin{array}{c}\text { Merdiven } \\
\text { basamak } \\
\text { sayısı }\end{array}$ & Teşvik & Mesaj & Desen & $\begin{array}{c}\text { Sonuç (merdiven } \\
\text { kullanımı)* }\end{array}$ & $\begin{array}{c}\text { Biçimlendi } \\
\text { rici kontrol } \\
\text { ya da } \\
\text { dişlama } \\
\text { değişkeni } \\
\end{array}$ \\
\hline $\begin{array}{l}\text { Blamey, Mutrie } \\
\text { ve Aitchison } \\
(1995)^{42}\end{array}$ & $\begin{array}{l}\text { Metro } \\
\text { ve } \\
\text { AVM }^{* *}\end{array}$ & 15 (x2 kat) & İşaret & $\begin{array}{l}\text { Sağlıklı kal, zaman } \\
\text { kazan, merdivenleri } \\
\text { kullan. }\end{array}$ & $\begin{array}{c}\text { 0-1hafta temel } \\
\text { düzey } \\
\text { 2-4hafta müdahale } \\
\text { 5-6hafta temel } \\
\text { düzeye dönüş } \\
\text { 10.hafta izleme1 } \\
\text { 18.hafta izleme2 }\end{array}$ & $\begin{array}{l}\text { Merdiven kullanma oranı } \\
\text { müdahale ve izleme } \\
\text { süreçlerinde temel } \\
\text { düzeyden yüksek }\end{array}$ & Cinsiyet \\
\hline $\begin{array}{l}\text { Anderson, } \\
\text { Franckowiak, } \\
\text { Snyder, Bartlett } \\
\text { ve Fontaine } \\
(1998)^{29}\end{array}$ & AVM & $\begin{array}{c}10+10(\mathrm{x} 6 \\
\text { kat })\end{array}$ & $\begin{array}{l}\text { Poster } \\
\text { (56x71) } \\
\text { (yere } \\
\text { yapıştırılm } \\
\text { ış) }\end{array}$ & $\begin{array}{c}\text { (Kalp simgesi) } \\
\text { Kalbinin egzersize } \\
\text { ihtiyacı var } \\
\text { merdivenleri kullan. } \\
\text { (sağlı mesajı) } \\
\text { (Merdiven çıkan } \\
\text { çöp adam) Bel } \\
\text { çevreni geliştir } \\
\text { merdivenleri kullan. } \\
\text { (kilo kontrolü } \\
\text { mesajı) } \\
\end{array}$ & $\begin{array}{l}\text { 0-1ay temel düzey } \\
\text { 1-2ay sağlık mesajı } \\
\text { müdahale } \\
\text { 2-3ay kilo kontrolü } \\
\text { müdahalesi }\end{array}$ & $\begin{array}{l}\text { Merdiven kullanma oranı } \\
\text { her iki müdahale sürecinde } \\
\text { temel düzeyden yüksek } \\
\text { Müdahaleler arası fark yok }\end{array}$ & $\begin{array}{l}\text { Cinsiyet, } \\
\text { yaş, kilo, } \\
\text { etnik köken }\end{array}$ \\
\hline $\begin{array}{l}\text { Kerr, Eves, } \\
\text { Carroll }(2000)^{43}\end{array}$ & AVM & & Poster & & $\begin{array}{c}\text { 0-2hafta temel } \\
\text { düzey } \\
\text { 3-6hafta müdahale }\end{array}$ & $\begin{array}{l}\text { Merdiven kullanma oranı } \\
\text { müdahale sürecinde temel } \\
\text { düzeyden yüksek }\end{array}$ & $\begin{array}{l}\text { Yaş, temel } \\
\text { düzeyde } \\
\text { hareketsizli } \\
\text { k oranı } \\
\end{array}$ \\
\hline $\begin{array}{l}\text { Coleman ve } \\
\text { Gonzales } \\
(2001)^{44}\end{array}$ & $\begin{array}{c}\text { Havaala } \\
\text { nı, } \\
\text { banka }\end{array}$ & $\begin{array}{c}\text { Havaalanı } \\
\text { ve banka } 2 \\
\text { katlı }\end{array}$ & $\begin{array}{c}\text { Poster } \\
(60 \times 60)\end{array}$ & $\begin{array}{l}\text { (Merdiven çıkan } \\
\text { kalp simgesi) } \\
\text { Kalbinin egzersize } \\
\text { ihtiyacı var. İşte } \\
\text { șansın. Adımına }\end{array}$ & $\begin{array}{c}\text { Temel düzey } \\
\text { Müdahale1 } \\
\text { Müdahale sonrası1 } \\
\text { Müdahale2 } \\
\text { Müdahale sonrası2 }\end{array}$ & $\begin{array}{c}\text { Bireysel } \\
\text { mesajlarda;bankada } \\
\text { merdiven kullanımı ilk } \\
\text { müdahale sürecinde ve ilk } \\
\text { müdahale sonrası }\end{array}$ & $\begin{array}{l}\text { Cinsiyet, } \\
\text { mekan, } \\
\text { mesaj tipi, } \\
\text { müdahale } \\
\text { tipi }\end{array}$ \\
\hline
\end{tabular}




\begin{tabular}{|c|c|c|c|c|c|c|c|}
\hline & & & & $\begin{array}{c}\text { dikkat et. (bireysel } \\
\text { mesaj) } \\
\text { (Merdiven çıkan } \\
\text { büyük ve iki küçük } \\
\text { kalp simgesi) Ailen } \\
\text { için yap. } \\
\text { Merdivenleri kullan. } \\
\text { Adımına dikkat et. } \\
\text { (aile mesajı) (Tüm } \\
\text { mesajlar İngilizce } \\
\text { ve İspanyolca) }\end{array}$ & & $\begin{array}{l}\text { sürecinde temel düzeyden } \\
\text { yüksek (cinsiyetler arası } \\
\text { fark yok); havaalanında } \\
\text { müdahale süreci, temel } \\
\text { düzey ve müdahale sonrası } \\
\text { sürecinden yüksek } \\
\text { (cinsiyetler arası fark yok), } \\
\text { ikinci müdahale sonrası } \\
\text { sürecinde ilk müdahale } \\
\text { sonrası sürecinden } \\
\text { kadınlarda yüksek, } \\
\text { erkeklerde fark yok. } \\
\text { Aile } \\
\text { mesajlarında;havaalanında } \\
\text { erkeklerde ilk müdahale } \\
\text { sonrası süreci ve ilk } \\
\text { müdahale süreci temel } \\
\text { düzeyden yüksek, } \\
\text { kadınlarda ilk müdahale } \\
\text { süreci, ilk müdahale sonrası } \\
\text { sürecinden ve temel } \\
\text { düzeyden yüksek. }\end{array}$ & \\
\hline \multirow[t]{2}{*}{$\begin{array}{l}\text { Kerr, Eves, } \\
\text { Carroll17 }\end{array}$} & AVM & 24 & $\begin{array}{c}\text { Poster } \\
\text { (42x30; } \\
\text { A3) } \\
6 \text { adet; } 4 \ddot{u} \\
\text { yukarıdan } \\
\text { asıll, 1i } \\
\text { merdiven } \\
\text { 1i yürüyen } \\
\text { merdiven } \\
\text { yanına } \\
\text { yapıştırılm } \\
\text { ıș }\end{array}$ & & $\begin{array}{l}\text { 2hafta temel düzey } \\
\text { 2hafta müdahale }\end{array}$ & $\begin{array}{l}\text { Merdiven kullanımı } \\
\text { müdahale sürecinde temel } \\
\text { düzeyden yüksek }\end{array}$ & $\begin{array}{l}\text { Cinsiyet, } \\
\text { insan } \\
\text { yoğunluğu }\end{array}$ \\
\hline & $\mathrm{AVM}$ & 30 & Poster & & 3hafta temel düzey & Merdiven kullanımı ilk & Cinsiyet, \\
\hline
\end{tabular}




\begin{tabular}{|c|c|c|c|c|c|c|c|}
\hline & & & $\begin{array}{c}(42 \times 30 ; \\
\text { A3, 60x42; } \\
\text { A2, } 84 \times 60 ; \\
\text { A1) }\end{array}$ & & $\begin{array}{c}\text { 2hafta } \\
\text { müdahale1(A3 } \\
\text { posteri) } \\
2 \text { hafta } \\
\text { müdahale2(A2 } \\
\text { posteri) } \\
\text { 2hafta } \\
\text { müdahale3(A1 } \\
\text { posteri) }\end{array}$ & $\begin{array}{c}\text { müdahalede temel } \\
\text { düzeyden farksız; ikinci } \\
\text { müdahalede üçüncü } \\
\text { müdahaleden farksız ve her } \\
\text { ikisinde temel düzey ve ilk } \\
\text { müdahaleden yüksek }\end{array}$ & $\begin{array}{c}\text { insan } \\
\text { yoğunluğu }\end{array}$ \\
\hline & $\begin{array}{c}\text { Tren } \\
\text { istasyo } \\
\text { nu }\end{array}$ & 39 & Poster & $\begin{array}{c}\text { Sağlıklı kal, } \\
\text { merdivenleri kullan. } \\
\text { (sağlık mesajı) } \\
\text { Sağlıklı kal, zaman } \\
\text { kazan, merdivenleri } \\
\text { kullan. (sağlık ve } \\
\text { zaman mesajı) } \\
\end{array}$ & $\begin{array}{l}\text { 2hafta temel düzey } \\
\text { 2hafta müdahale1 } \\
\text { (sağlık mesajı) } \\
\text { 2hafta müdahale2 } \\
\text { (sağlık ve zaman } \\
\text { mesajı) }\end{array}$ & $\begin{array}{c}\text { Merdiven kullanımı ilk } \\
\text { müdahale sürecinde temel } \\
\text { düzeyden; ikinci müdahale } \\
\text { sürecinde ise temel düzey } \\
\text { ve ilk müdahale sürecinden } \\
\text { yüksek }\end{array}$ & $\begin{array}{l}\text { Cinsiyet, } \\
\text { insan } \\
\text { yoğunluğu }\end{array}$ \\
\hline & AVM & 24 & Poster & $\begin{array}{c}\text { Sağlıklı kal, } \\
\text { merdivenleri kullan. } \\
\text { (sağlık mesajı) } \\
\text { Sağlıklı kal, zaman } \\
\text { kazan, merdivenleri } \\
\text { kullan. (sağlık ve } \\
\text { zaman mesajı) } \\
\end{array}$ & $\begin{array}{l}\text { 2hafta temel düzey } \\
\text { 2hafta müdahale1 } \\
\text { (sağlık mesajı) } \\
\text { 2hafta müdahale2 } \\
\text { (sağlık ve zaman } \\
\text { mesajı) }\end{array}$ & $\begin{array}{c}\text { Merdiven kullanımı ilk } \\
\text { müdahale sürecinde temel } \\
\text { düzeyden yüksek; ikinci } \\
\text { müdahale sürecinde ise ilk } \\
\text { müdahale sürecinden } \\
\text { farksız, temel düzeyden } \\
\text { yüksek. }\end{array}$ & $\begin{array}{l}\text { Cinsiyet, } \\
\text { insan } \\
\text { yoğunluğu }\end{array}$ \\
\hline $\begin{array}{l}\text { Kerr, Eves, } \\
\text { Carroll }(2001)^{45}\end{array}$ & AVM & 24 & Şerit & $\begin{array}{l}\text { Merdivenleri kullan. } \\
\text { Sağlıklı kal. Günlük } \\
\text { Egzersiz. } \\
\text { Bacaklarını çalıştır. } \\
\text { Merdivenleri kullan. } \\
\text { Bedava egzersiz. } \\
\text { Sağlıklı kal. Kolay } \\
\text { egzersiz. } \\
\text { Merdivenleri kullan. } \\
\text { Etkin ol. Kalbini } \\
\text { çalıştır. Aferin. }\end{array}$ & $\begin{array}{c}\text { 2hafta temel düzey } \\
\text { 12hafta müdahale } \\
\text { 2hafta izleme }\end{array}$ & $\begin{array}{c}\text { Merdiven kullanımı } \\
\text { müdahale sürecinde temel } \\
\text { düzey ve izleme sürecinden } \\
\text { yüksek, izleme sürecinde } \\
\text { müdahale sürecinden } \\
\text { düşük temel düzeyden } \\
\text { yüksek. }\end{array}$ & $\begin{array}{l}\text { Cinsiyet, } \\
\text { yaş, etnik } \\
\text { köken, } \\
\text { insan } \\
\text { yoğunluğu }\end{array}$ \\
\hline
\end{tabular}




\begin{tabular}{|c|c|c|c|c|c|c|c|}
\hline $\begin{array}{l}\text { Kerr, Eves, } \\
\text { Carroll }(2001)^{46}\end{array}$ & AVM & 24 & Şerit & $\begin{array}{l}\text { Merdivenleri kullan. } \\
\text { Sağlıklı kal. Günlük } \\
\text { Egzersiz. } \\
\text { Bacaklarını çalıștır. } \\
\text { Merdivenleri kullan. } \\
\text { Bedava egzersiz. } \\
\text { Sağlıklı kal. Kolay } \\
\text { egzersiz. } \\
\text { Merdivenleri kullan. } \\
\text { Etkin ol. Kalbini } \\
\text { çalıștır. Aferin. }\end{array}$ & $\begin{array}{l}\text { 2hafta temel düzey } \\
\text { 6hafta müdahale }\end{array}$ & $\begin{array}{c}\text { Merdiven kullanımı } \\
\text { müdahale sürecinde temel } \\
\text { düzeyden yüksek. }\end{array}$ & $\begin{array}{l}\text { Cinsiyet, } \\
\text { yaș, etnik } \\
\text { köken, } \\
\text { insan } \\
\text { yoğunluğu }\end{array}$ \\
\hline $\begin{array}{l}\text { Kerr, Eves, } \\
\text { Carroll }(2001)^{47}\end{array}$ & $\begin{array}{l}\text { AVM } \\
\text { (biri } \\
\text { deney } \\
\text { biri } \\
\text { kontrol } \\
\text { alanı } \\
\text { olarak 2 } \\
\text { farklı) }\end{array}$ & 28 & $\begin{array}{c}\text { Şerit } \\
\text { Poster }\end{array}$ & $\begin{array}{l}\text { Merdivenleri kullan. } \\
\text { Sağlıklı kal. Günlük } \\
\text { Egzersiz. } \\
\text { Bacaklarını çalıştır. } \\
\text { Merdivenleri kullan. } \\
\text { Bedava egzersiz. } \\
\text { Sağlıklı kal. Kolay } \\
\text { egzersiz. } \\
\text { Merdivenleri kullan. } \\
\text { Etkin ol. Kalbini } \\
\text { çalıştır. Aferin. } \\
\text { (Şerit) } \\
\text { Sağlıklı kal } \\
\text { merdivenleri kullan. } \\
\text { (Poster) }\end{array}$ & $\begin{array}{l}\text { 2hafta temel düzey } \\
\text { 2hafta müdahale1 } \\
\text { (poster) } \\
\text { 2hafta müdahale2 } \\
\text { (şerit) }\end{array}$ & $\begin{array}{c}\text { Merdiven kullanımı ilk } \\
\text { müdahale sürecinde her iki } \\
\text { AVM için de temel } \\
\text { düzeyden yüksek, ikinci } \\
\text { müdahale sürecinde ise } \\
\text { yalnızca deney alanı olan } \\
\text { AVM için ilk müdahale } \\
\text { süreci ve temel düzeyden } \\
\text { yüksek. }\end{array}$ & $\begin{array}{l}\text { Cinsiyet, } \\
\text { yaș, etnik } \\
\text { köken, } \\
\text { insan } \\
\text { yoğunluğu }\end{array}$ \\
\hline $\begin{array}{l}\text { Webb ve Eves } \\
(2005)^{48}\end{array}$ & AVM & 24 & Şerit & $\begin{array}{l}\text { Merdivenleri kullan. } \\
\text { Sağlıklı kal. Günlük } \\
\text { Egzersiz. } \\
\text { Bacaklarını çalıştır. } \\
\text { Merdivenleri kullan. } \\
\text { Bedava egzersiz. } \\
\text { Sağlıklı kal. Kolay } \\
\text { egzersiz. } \\
\text { Merdivenleri kullan. }\end{array}$ & $\begin{array}{l}\text { 2hafta temel düzey } \\
\text { 2hafta müdahale1 } \\
\text { (8 basamakta } \\
\text { "Sağlıklı kal." mesajı } \\
\text { ve bir "Merdivenleri } \\
\text { kullan." mesajı. } \\
\text { 2hafta müdahale2 } \\
\text { tüm mesajlar }\end{array}$ & $\begin{array}{l}\text { Merdiven kullanımı ilk } \\
\text { müdahale ve ikinci } \\
\text { müdahale sürecinde } \\
\text { birbirinden farksız ancak } \\
\text { temel düzeyden yüksek. }\end{array}$ & $\begin{array}{c}\text { İnsan } \\
\text { yoğunluğu, } \\
\text { etnik köken, } \\
\text { valiz/büyük } \\
\text { çanta } \\
\text { taşıma, yaş }\end{array}$ \\
\hline
\end{tabular}




\begin{tabular}{|c|c|c|c|c|c|c|c|}
\hline & & & & $\begin{array}{l}\text { Etkin ol. Kalbini } \\
\text { çalıştır. Aferin. }\end{array}$ & & & \\
\hline $\begin{array}{l}\text { Andersen, } \\
\text { Franckowiak, } \\
\text { Zuzak, } \\
\text { Cummings, } \\
\text { Bartlett ve } \\
\text { Crespo }(2005)^{49}\end{array}$ & Metro & $\begin{array}{c}16+16(6 \\
\text { adımlık } \\
\text { ara ile) }\end{array}$ & $\begin{array}{l}\text { Poster } \\
(47 x 71)\end{array}$ & $\begin{array}{l}\text { (Merdiven çlkan } \\
\text { siyahi kadın } \\
\text { simgesi) Egzersiz } \\
\text { için zamanınız mı } \\
\text { yok? Merdivenleri } \\
\quad \text { deneyin. }\end{array}$ & $\begin{array}{c}\text { 2hafta temel } \\
\text { düzey1 } \\
\text { 2hafta müdahale1 } \\
\text { 1hafta izleme } \\
\text { 1hafta ara } \\
\text { 1hafta temel } \\
\text { düzey2 } \\
\text { 1hafta müdahale2 }\end{array}$ & $\begin{array}{l}\text { Merdiven kullanımı ilk } \\
\text { müdahale ve izleme } \\
\text { sürecinde ilk temel } \\
\text { düzeyden yüksek, ikinci } \\
\text { müdahale sürecinde ikinci } \\
\text { temel düzeyden yüksek, } \\
\text { her iki temel düzey } \\
\text { sürecinde benzer. Siyahiler } \\
\text { için; merdiven kullanımı } \\
\text { izleme sürecinde temel } \\
\text { düzeyden yüksek } \\
\text { Beyazlar için; merdiven } \\
\text { kullanımı izleme ve ara } \\
\text { sürecinde temel düzeyden } \\
\text { yüksek } \\
\end{array}$ & $\begin{array}{l}\text { Yaş, etnik } \\
\text { köken, kilo, } \\
\text { çocuklu } \\
\text { olma, } \\
\text { valiz/büyük } \\
\text { çanta } \\
\text { taşıma }\end{array}$ \\
\hline $\begin{array}{l}\text { Iversen, Händel, } \\
\text { Jensen, } \\
\text { Frederiksen ve } \\
\text { Heitmann } \\
(2007)^{50}\end{array}$ & $\begin{array}{l}\text { Metro } \\
(2 \\
\text { farklı) }\end{array}$ & $\begin{array}{l}31(1 \\
\text { adımlık } \\
\text { ara) } \\
17(2 \\
\text { adımlık } \\
\text { ara) }\end{array}$ & $\begin{array}{l}\text { Poster } \\
\text { (58x77; } \\
\text { A1) }\end{array}$ & $\begin{array}{l}\text { (Merdiven çlkan } \\
\text { kalp simgesi) } \\
\text { Merdivenleri kullan } \\
\text { sağlıklı kal. }\end{array}$ & $\begin{array}{c}\text { 1hafta temel düzey } \\
\text { 1hafta müdahale } \\
\text { 1hafta müdahale } \\
\text { sonrası } \\
2 \text { yıl sonra izleme }\end{array}$ & $\begin{array}{l}\text { Merdiven kullanımı her iki } \\
\text { istasyonda da müdahale } \\
\text { sürecinde ve iki yıl sonrası } \\
\text { izlemede temel düzeyden } \\
\text { yüksek; yalnızca } 34 \\
\text { basamaklı metroda ise iki } \\
\text { yll sonrası izleme müdahale } \\
\text { sonrası sürecinden düşük. }\end{array}$ & cinsiyet \\
\hline $\begin{array}{l}\text { Olander, Eves ve } \\
\text { Puig-Ribera } \\
(2008)^{22}\end{array}$ & $\begin{array}{c}\text { Tren } \\
\text { istasyo } \\
\mathrm{nu}\end{array}$ & 39 & $\begin{array}{c}\text { Şerit } \\
\text { Poster } \\
\text { (A1) } \\
\text { (yere } \\
\text { yapıștırılm } \\
\text { Iş) }\end{array}$ & $\begin{array}{l}\text { Merdiven çıkmak } \\
\text { bir dakika hafif } \\
\text { tempolu koşudan } \\
\text { daha fazla kalori } \\
\text { yakar...merdivenler } \\
\text { i kullan. }\end{array}$ & $\begin{array}{c}\text { 3,5hafta temel } \\
\text { düzey } \\
\text { 10,5hafta } \\
\text { müdahale1 (şerit) } \\
\text { 3h müdahale2 } \\
\text { (şerit+poster) }\end{array}$ & $\begin{array}{l}\text { Merdiven kullanımı ilk } \\
\text { müdahale sürecinde ve } \\
\text { temel düzeyde birbirinden } \\
\text { farksız, ikinci müdahale } \\
\text { sürecinde ise her ikisinden } \\
\text { yüksek. }\end{array}$ & $\begin{array}{l}\text { İnsan } \\
\text { yoğunluğu, } \\
\text { çocuklu } \\
\text { olma, } \\
\text { valiz/büyük } \\
\text { çanta } \\
\text { taşıma, } \\
\text { cinsiyet }\end{array}$ \\
\hline
\end{tabular}




\begin{tabular}{|c|c|c|c|c|c|c|c|}
\hline $\begin{array}{l}\text { Puig-Ribera ve } \\
\text { Eves }(2009)^{51}\end{array}$ & Metro & 24 & Şerit & $\begin{array}{c}\text { Sağlıklı kal, } \\
\text { merdivenleri kullan. } \\
\text { Sağlıklı kal, zaman } \\
\text { kazan, merdivenleri } \\
\text { kullan. } \\
\text { Günde } 7 \text { dakikalık } \\
\text { merdiven çıkma } \\
\text { kalbini korur. } \\
\text { (Katalanca ve } \\
\text { İspanyolca) } \\
\end{array}$ & $\begin{array}{c}\text { 2hafta temel düzey } \\
\text { 2x3hafta müdahale } \\
\text { 11.hafta izleme }\end{array}$ & $\begin{array}{l}\text { Merdiven kullanımı hem } \\
\text { izleme sürecinde hem de } \\
\text { müdahale sürecinde temel } \\
\text { düzeyden yüksek. }\end{array}$ & $\begin{array}{c}\text { Cinsiyet, } \\
\text { yaş, etnik } \\
\text { köken, } \\
\text { insan } \\
\text { yoğunluğu, } \\
\text { çocuklu } \\
\text { olma, } \\
\text { valiz/büyük } \\
\text { çanta } \\
\text { taşıma } \\
\end{array}$ \\
\hline $\begin{array}{l}\text { Nomura, } \\
\text { Yoshimoto, } \\
\text { Akezaki ve Sato } \\
(2009)^{52}\end{array}$ & $\begin{array}{c}\text { Tren } \\
\text { istasyo } \\
\text { nu }\end{array}$ & 37 (aralı) & $\begin{array}{c}\text { Şerit } \\
\text { Poster } \\
(42 \times 59 ; \\
90 \times 90,4 \\
\text { adet) } \\
\text { Gazete } \\
\text { ilanı }\end{array}$ & $\begin{array}{c}\text { Merdivenleri yukarı } \\
\text { çık. Bacaklarını } \\
\text { çalıştır. Yürü ve } \\
\text { sağlıklı ol. } \\
\text { Merdivenleri kullan. } \\
\text { Hastalıktan } \\
\text { korunmak için. } \\
\text { Bedava egzersiz. } \\
\text { Günlük hayatta } \\
\text { egzersiz. Kalbini } \\
\text { çalıştır. Günlük } \\
\text { egzersiz. Daha fazla } \\
\text { egzersiz yap. } \\
\text { Devamlılık önemli. } \\
\text { Aferin. (Şerit) Kısa } \\
\text { süreli egzersiz } \\
\text { sonrası yüksek } \\
\text { enerji emilim } \\
\text { durumu sağlanır. } \\
\text { Vücudunu günlük } \\
\text { hayatta daha sık } \\
\text { hareket ettirirsen } \\
\text { düşündüğ̈nden } \\
\text { daha fazla enerji } \\
\text { harcarsın. Örneğin }\end{array}$ & $\begin{array}{c}\text { 2hafta temel düzey } \\
\text { 4hafta müdahale } \\
\text { 9. hafta izleme }\end{array}$ & $\begin{array}{c}\text { Merdiven kullanımı } \\
\text { müdahale sürecinde temel } \\
\text { düzeyden yüksek, izleme } \\
\text { sürecinde ise temel } \\
\text { düzeyden farksız. } \\
\text { Gazete ilanı etkisiz. }\end{array}$ & $\begin{array}{l}\text { Cinsiyet, } \\
\text { Yaş }\end{array}$ \\
\hline
\end{tabular}




\begin{tabular}{|c|c|c|c|c|c|c|c|}
\hline & & & & $\begin{array}{c}\text { merdivenler kullan, } \\
\text { çamaşır yıka. TV } \\
\text { uzaktan kumandası } \\
\text { kullanma. (Büyük } \\
\text { posterler) Yürü. } \\
\text { (Küçük poster) } \\
\text { (Küçük poster } \\
\text { İngilizce, diğerleri } \\
\text { Japonca) } \\
\end{array}$ & & & \\
\hline $\begin{array}{l}\text { Müller- } \\
\text { Riemenschneide } \\
\text { r, Nocon, } \\
\text { Reinhold ve } \\
\text { Willich }(2010)^{53}\end{array}$ & Metro & & $\begin{array}{c}\text { Poster } \\
\text { (59x84; } \\
\text { A1) }\end{array}$ & $\begin{array}{c}\text { Beni kullan! } \\
\text { Merdivenin. } \\
\text { Basamak göreve } \\
\text { çağırıor! (alt } \\
\text { metin) (Almanca) }\end{array}$ & $\begin{array}{c}\text { 0 temel düzey } \\
\text { 1-5hafta müdahale } \\
\text { 10.hafta müdahale } \\
\text { sonrası }\end{array}$ & $\begin{array}{c}\text { Merdiven kullanımı, } \\
\text { kadınlarda müdahalenin } 1 . \\
\text { ve } 5 \text {. haftasında ve } \\
\text { müdahale sonrası süreçte } \\
\text { temel düzeyden yüksek. } \\
\text { Erkeklerde fark yok. }\end{array}$ & $\begin{array}{c}\text { İnsan } \\
\text { yoğunluğu, } \\
\text { cinsiyet }\end{array}$ \\
\hline $\begin{array}{l}\text { Webb ve Cheng } \\
(2010)^{54}\end{array}$ & $\mathrm{AVM}$ & 38 & Şerit & $\begin{array}{c}\text { Merdiven çıkmak } \\
\text { bir dakika hafif } \\
\text { tempolu koşudan } \\
\text { daha fazla kalori } \\
\text { yakar...merdivenler } \\
\text { i kullan. }\end{array}$ & $\begin{array}{l}\text { 2hafta temel düzey } \\
\text { 5hafta müdahale }\end{array}$ & $\begin{array}{c}\text { Merdiven kullanımı } \\
\text { müdahale süreci temel } \\
\text { düzey farkı kilolularda } \\
\text { zayıflardan yüksek. }\end{array}$ & $\begin{array}{c}\text { İnsan } \\
\text { yoğunluğu, } \\
\text { cinsiyet, } \\
\text { etnik köken, } \\
\text { kilo, } \\
\text { valiz/büyük } \\
\text { çanta } \\
\text { taşıma } \\
\end{array}$ \\
\hline \multirow[t]{2}{*}{$\begin{array}{l}\text { Boen, Maurissen } \\
\text { ve Opdenacker } \\
(2010)^{55}\end{array}$} & AVM & $\begin{array}{c}34(7 . \\
\text { basamakta } \\
\text { ara) }\end{array}$ & $\begin{array}{l}\text { Poster } \\
\text { (A1) }\end{array}$ & $\begin{array}{c}\text { Formda kal, } \\
\text { merdivenleri kullan. }\end{array}$ & $\begin{array}{l}\text { Her düzey arası } \\
\text { 1hafta ara ile; } \\
\text { 1gün temel düzey } \\
\text { 1gün müdahale1 } \\
\text { 1gün müdahale } \\
\text { sonrası } \\
\text { 1gün müdahale2 } \\
\text { (müdahalenin } \\
\text { tekrar tanıtılması) }\end{array}$ & $\begin{array}{l}\text { Merdiven kullanımı her iki } \\
\text { müdahale sürecinde } \\
\text { birbirinden farksız, her } \\
\text { ikisi de temel düzeyden } \\
\text { yüksek, müdahale sonrası } \\
\text { sürecinde temel düzeyden } \\
\text { yüksek müdahale } \\
\text { sürecinden düşük. }\end{array}$ & $\begin{array}{l}\text { Valiz/büyük } \\
\text { çanta } \\
\text { taşıma, } \\
\text { çocuklu ya } \\
\text { da hamile } \\
\text { olma, } \\
\text { engelli olma }\end{array}$ \\
\hline & $\begin{array}{l}\text { Tren } \\
\text { istasyo }\end{array}$ & $\begin{array}{l}40 \text { (her } 10 . \\
\text { basamakta }\end{array}$ & $\begin{array}{l}\text { Poster } \\
\text { (A1) }\end{array}$ & $\begin{array}{c}\text { Formda kal, } \\
\text { merdivenleri kullan. }\end{array}$ & $\begin{array}{c}\text { Art arda; } \\
\text { 1gün temel düzey }\end{array}$ & $\begin{array}{l}\text { Merdiven kullanımı } \\
\text { müdahale sonrası }\end{array}$ & $\begin{array}{c}\text { Valiz/büyük } \\
\text { çanta }\end{array}$ \\
\hline
\end{tabular}




\begin{tabular}{|c|c|c|c|c|c|c|c|}
\hline & nu & ara) & & & $\begin{array}{l}\text { 1gün müdahale1 } \\
\text { 1gün müdahale } \\
\text { sonrası } \\
\text { 1gün müdahale2 } \\
\text { (müdahalenin } \\
\text { tekrar tanitılması) }\end{array}$ & $\begin{array}{l}\text { sürecinde ve temel düzeyde } \\
\text { birbirinden farksız, ilk } \\
\text { müdahale sürecinde her } \\
\text { ikisinden yüksek. }\end{array}$ & $\begin{array}{c}\text { taşıma, } \\
\text { çocuklu ya } \\
\text { da hamile } \\
\text { olma, } \\
\text { engelli olma }\end{array}$ \\
\hline & $\begin{array}{l}\text { Tren } \\
\text { istasyo } \\
\text { nu }\end{array}$ & $\begin{array}{l}40 \text { (her } 10 . \\
\text { basamakta } \\
\text { ara) }\end{array}$ & $\begin{array}{l}\text { Poster } \\
\text { (A1) }\end{array}$ & $\begin{array}{c}\text { Formda kal, } \\
\text { merdivenleri kullan. }\end{array}$ & $\begin{array}{c}\text { Art arda; } \\
\text { 1gün temel düzey } \\
\text { 1gün müdahale1 } \\
\text { 1gün müdahale } \\
\text { sonrası1 } \\
\text { 1gün müdahale2 } \\
\text { (müdahalenin } \\
\text { tekrar tanıtılması) } \\
\text { 1gün müdahale } \\
\text { sonrası2 }\end{array}$ & $\begin{array}{c}\text { Merdiven kullanımı } \\
\text { müdahale sonrası } \\
\text { sürecinde ve temel düzeyde } \\
\text { birbirinden farksız, ilk } \\
\text { müdahale sürecinde her } \\
\text { ikisinden yüksek, ikinci } \\
\text { müdahale sürecinde temel } \\
\text { düzey ve ilk müdahale } \\
\text { sürecinden yüksek, ikinci } \\
\text { müdahale sonrası süreçte } \\
\text { ikinci müdahale sürecinden } \\
\text { düşük, ikinci müdahale } \\
\text { sonrası sürecinde temel } \\
\text { düzeyden yüksek. }\end{array}$ & $\begin{array}{l}\text { Valiz/büyük } \\
\text { çanta } \\
\text { taşıma, } \\
\text { çocuklu ya } \\
\text { da hamile } \\
\text { olma, } \\
\text { engelli olma }\end{array}$ \\
\hline $\begin{array}{l}\text { Ryan, Lyon, } \\
\text { Webb, Eves ve } \\
\text { Ryan }(2011)^{56}\end{array}$ & $\begin{array}{l}\text { Metro } \\
(2 \\
\text { farklı) }\end{array}$ & $\begin{array}{l}30 \text { (Yüksek } \\
\text { SED) } \\
22 \text { (Düşük } \\
\text { SED) }\end{array}$ & $\begin{array}{l}\text { Poster } \\
\text { (A1) } \\
\text { (merdiveni } \\
\text { n yanına } \\
\text { yapıștırılm } \\
\text { ış) } \\
\end{array}$ & $\begin{array}{l}\text { Sağllklı kal, zaman } \\
\text { kazan, merdivenleri } \\
\text { kullan. }\end{array}$ & $\begin{array}{c}0 \text { temel düzey } \\
\text { 5hafta müdahale } \\
\text { 7.hafta izleme }\end{array}$ & $\begin{array}{l}\text { Merdiven kullanımı } \\
\text { müdahale ve izleme } \\
\text { sürecinde birbirinden } \\
\text { farksız her ikisi de temel } \\
\text { düzeyden yüksek. }\end{array}$ & $\begin{array}{c}\text { İnsan } \\
\text { yoğunluğu, } \\
\text { sosyoekono } \\
\text { mik düzey, } \\
\text { cinsiyet }\end{array}$ \\
\hline $\begin{array}{l}\text { Lewis ve Eves } \\
(2012)^{8}\end{array}$ & $\begin{array}{l}\text { Tren } \\
\text { istasyo } \\
\text { nu }\end{array}$ & 43 & $\begin{array}{l}\text { Poster } \\
\text { (A1) (iki } \\
\text { adet biri } \\
\text { merdivenl } \\
\text { erin } \\
\text { altında biri } \\
\text { üstünde) }\end{array}$ & $\begin{array}{l}\text { Düzenli merdiven } \\
\text { kullanmak kilo } \\
\text { almayı engeller. } \\
\text { (poster1) } \\
\text { Aferin merdiven } \\
\text { kullananlar! Tam } \\
\text { şimdi kilo vermeniz } \\
\text { için gereken } 16 . \\
\end{array}$ & $\begin{array}{c}\text { 2hafta temel } \\
\text { düzey1 } \\
\text { 2hafta müdahale1 } \\
\text { (poster1) } \\
\text { 6hafta müdahale2 } \\
\text { (poster1+poster2) } \\
\text { 4hafta ara (poster } \\
\text { kaldırılmış) } \\
\end{array}$ & $\begin{array}{l}\text { Merdiven kullanımı } \\
\text { müdahale1 sürecinde ve } \\
\text { temel düzey1 birbirinden } \\
\text { farksız, müdahale2 } \\
\text { sürecinde her ikisinden } \\
\text { yüksek, ara dönemde } \\
\text { müdahale2den farksız, } \\
\text { temel düzey2de temel } \\
\end{array}$ & $\begin{array}{c}\text { İnsan } \\
\text { yoğunluğu, } \\
\text { cinsiyet }\end{array}$ \\
\hline
\end{tabular}




\begin{tabular}{|c|c|c|c|c|c|c|c|}
\hline & & & & $\begin{array}{l}\text { Kiloyu yaktınız. } \\
\text { (poster2) }\end{array}$ & $\begin{array}{c}\text { 2hafta temel } \\
\text { düzey2 } \\
\text { 4hafta müdahale3 } \\
\text { (poster2) } \\
\text { 2hafta müdahale4 } \\
\text { (müdahale2 tekrar } \\
\text { tanitılmış) }\end{array}$ & $\begin{array}{l}\text { düzey1den yüksek, } \\
\text { müdahale3te } \\
\text { temeldüzey2den farksız, } \\
\text { müdahale4 sürecinde } \\
\text { müdahale3 sürecinden } \\
\text { yüksek. }\end{array}$ & \\
\hline $\begin{array}{l}\text { Sloan, Haaland, } \\
\text { Leung ve Müller- } \\
\text { Riemenschneider } \\
(2013)^{57}\end{array}$ & $\begin{array}{c}\text { Tren } \\
\text { istasyo } \\
\text { nu (biri } \\
\text { deney } \\
\text { biri } \\
\text { kontrol } \\
\text { alanı } \\
\text { olarak 2 } \\
\text { farklı) }\end{array}$ & 30 & $\begin{array}{l}\text { Poster } \\
\text { (16x328) } \\
\text { yere } \\
\text { yapıștırılm } \\
\text { 1ş) } \\
\text { Şerit }\end{array}$ & $\begin{array}{c}\text { (Merdiven çlkan } \\
\text { adam simgesi) } \\
\text { Haftada } 150 \text { dakika } \\
\text { fiziksel aktivite } \\
\text { hedefle. (Merdiven } \\
\text { çlkan adam } \\
\text { simgesi) Formda } \\
\text { kalmak için } \\
\text { merdivenleri } \\
\text { çıkmak istiyorum. } \\
\text { (Posterler) Formda } \\
\text { kalmak için } \\
\text { merdivenleri } \\
\text { çıkmak istiyorum. } \\
\text { Daha sağlıklı bir } \\
\text { bene adımlıyorum. } \\
\text { Merdiven } \\
\text { kullanarak } 2 \text { kat } \\
\text { daha fazla kalori } \\
\text { yaktım. (Şeritler) }\end{array}$ & $\begin{array}{l}\text { 2hafta temel düzey } \\
\text { 4hafta müdahale } \\
\text { 2hafta müdahale } \\
\text { sonrası }\end{array}$ & $\begin{array}{l}\text { Merdiven kullanımı } \\
\text { müdahale sürecinde ve } \\
\text { müdahale sonrası } \\
\text { sürecinde temel düzeyden } \\
\text { yüksek. }\end{array}$ & $\begin{array}{c}\text { İnsan } \\
\text { yoğunluğu, } \\
\text { cinsiyet }\end{array}$ \\
\hline
\end{tabular}

* Sonuç değişkeni bakımından yalnızca merdiven çıkma davranışı ele alınmıștır. **AVM: alış veriş merkezi 